\title{
ISOLATION OF ANTIOXIDANTS FROM Alchemilla xanthochlora
}

\author{
MIROSLAV ONDREJOVIČ ${ }^{1,2}$, ZUZANA ONDRIGOVÁ $^{1}$ \\ JANKA KUBINCOVÁ ${ }^{2}$
}

\author{
${ }^{I}$ Department of Biotechnology, University of SS. Cyril and Methodius, J. Herdu 2, \\ Trnava, SK-917 01, Slovak Republic (miroslavondrejovic@gmail.com) \\ ${ }^{2}$ Food Research Institute, dept. Biocentre, Kostolna 7, SK-900 01, Modra, \\ Slovak Republic
}

\begin{abstract}
The aim of this study was to find conditions for isolation of antioxidants from Alchemilla xanthochlora. The solid-liquid extraction of plant material with different solvents (n-hexane, chloroform, ethylacetate, methanol, and water) was used for preparation of crude extracts of antioxidants. For additional purification of crude extract, liquid-liquid extraction in different organic solvents (chloroform, ethylacetate, methanol) and water, and column chromatography with silica gel as stationary phase and mixture of chloroform : methanol as mobile phase were used. The content of active compounds was monitored by photometric method and special TLC analysis using DPPH as basic reagent. TLC-DPPH analysis of herbal extracts showed that antioxidants from Alchemilla xanthochlora were separated into two groups with different polarity. Finally, for the isolation of antioxidants from Alchemilla xanthochlora were successfully used the following procedures: extraction of dried grounded plant material with methanol at $50^{\circ} \mathrm{C}$ during 1 hour, subsequent liquid-liquid extraction in isopropanol and water and fractionation of isopropanol extract by column chromatography. Fraction with isolated antioxidants showed antioxidant activity $535.2 \mathrm{mg}$ to $\mathrm{g}$ of fraction residue.
\end{abstract}

Keywords: antioxidants, Alchemilla xanthochlora, extraction, purification

\section{Introduction}

Alchemilla xanthochlora belongs to the somniferous herbs from the family Rosaceae. It is commonly used for the locally treatment of various skin diseases. The antibacterial activity of this plant was related with its tannin content (DJIPA et al., 2000). In recent study, Alchemilla xanthochlora was presented as herb with enormous antioxidant activity (TROUILLAS et al., 2003; HAMAD et al., 2007) comparable with commonly used antioxidant sources such as strawberry, blackberry or raspberry (FIKSELOVÁ and IVANIŠOVÁ, 2008).

Various assays have been used for the analysis of natural antioxidants but the mostly widely used methods are those that involve generation of free radical species which are then neutralised by antioxidant compounds (ARNAO et al., 2001). The DPPH method measures electron-donating activity of other compounds in the mixture and hence provides an evaluation of antioxidant activity due to free radical scavenging. Any molecule that can donate an electron or hydrogen to a mixture will react with and bleach DPPH. In qualitative analysis of antioxidants, the 2,2-diphenyl1-picrylhydrazyl (DPPH) assay on TLC plates was used as a screening test for the radical scavenging ability of the compounds present in the different extracts (NAIK et al., 2003). 
The aim of the present study was to evaluate the antioxidant activities of various solvent extracts and fractions acquired by solid-liquid and liquid-liquid extraction and column chromatography from Alchemilla xanthochlora, and choose an extraction system suitable for isolation responsible compounds.

\section{Material and methods}

\subsection{Plant material}

Adult leaves of Alchemilla xanthochlora were harvested with the twigs and dried at $40^{\circ} \mathrm{C}$. Thereafter, the leaves were separated from the twigs and cut in small squares of $1-1.5 \mathrm{~cm}^{2}$. This extraction material was stored in powder flask at laboratory temperature.

\subsection{Preparation of extracts}

$1 \mathrm{~g}$ of plant material was extracted with $20 \mathrm{ml}$ of extraction solvent (hexane, chloroform, ethylacetate, methanol and distilled water) over 1 hour at $50^{\circ} \mathrm{C}$. The extraction mixture was centrifuged at $3000 \mathrm{x} g$ for 10 minutes and the supernatant was decanted. The solvent was removed under reduced pressure on the rotary vacuum evaporator at $50^{\circ} \mathrm{C}$. The solid residue was solubilized in mixture of chloroform and water and water phase enhanced with saturated water solution of $\mathrm{NaCl}$ was further extracted with ethylacetate and isopropanol, respectively. The isopropanol fraction $(10 \mathrm{ml})$ was fractionated on a silica gel $(20 \mathrm{~g})$ eluted with chloroform: methanol (10:0; $9: 1 ; 7: 1 ; 5: 1 ; 3: 1 ; 1: 1 ; 0: 10)$. Totally 21 fractions was analysed by TLC-DPPH and photometric DPPH analysis.

\subsection{TLC-DPPH analysis}

Chemical constituents of plant extracts were analysed by thin layer chromatography (TLC) using aluminium-backed TLC plates (Silica gel 60 F254). The TLC plates were developed with four following mobile phases as methanol: formic acid (10:1) (developing to $1 / 4$ of TLC plate length), chloroform : methanol (9:1) (developing to $1 / 2$ of TLC plate length), toluene: acetone (7:3) (developing to $3 / 4$ of TLC plate length) and hexane: ethylacetate (5:1) (complete developing of TLC plate) respectively. Between developing in mobile phases the plates were dried in the fume hood at $50{ }^{\circ} \mathrm{C}$. To detect antioxidant compounds, chromatograms were sprayed with $0.2 \%$ 2,2-diphenyl-2-picryl-hydrazyl (DPPH) in methanol, as an indicator. The presence of antioxidant compounds was detected by yellow spots against a purple background.

\subsection{Photometric DPPH analysis}

The DPPH assay was performed as described (PAULOVÁ et al., 2004). In this assay, BHT (butylhydroxytoluene) was used as positive control, and reaction mixtures 
contained a methanolic solution of $150 \mu \mathrm{M}$ DPPH $(100 \mu \mathrm{l})$ and sample $(25 \mu \mathrm{l})$ placed in a 96 well microplate and incubated at laboratory temperature for 10 minutes. After incubation, the absorbance was read at $517 \mathrm{~nm}$ and the radical-scavenging activity was determined by the following equation:

$$
\text { DPPH activity }=\left[\left(\mathrm{A}_{\mathrm{c}}-\mathrm{A}_{\mathrm{s}}\right) / \mathrm{A}_{\mathrm{c}} \times 100\right] \times \mathrm{m}_{\mathrm{DPPH}} / \mathrm{m}_{\mathrm{rs}}
$$

where $A_{s}$ is absorbance of reaction mixtures with sample, $A_{c}$ is absorbance of reaction mixtures with methanol instead of sample, $\mathrm{m}_{\mathrm{DPPH}}$ is calculated mass of DPPH in reaction mixture and $\mathrm{m}_{\mathrm{rs}}$ is calculated mass of extract/fraction residue.

\section{Results and discussion}

Screening of antioxidants from Alchemilla xanthochlora was made by preparation of crude extract with extraction solvents such as hexane, chloroform, ethylacetate, methanol and water. Selected extraction solvents can extract a wide range of natural compounds from plant material.

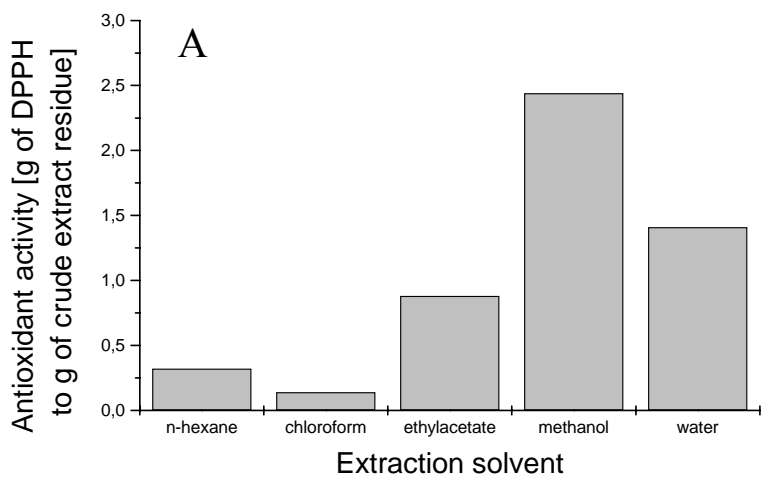

$\mathrm{B}$

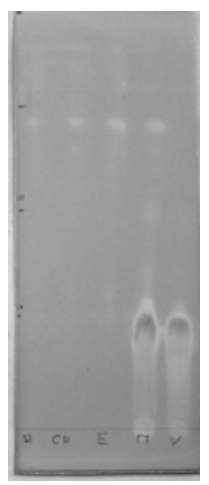

Fig. 1. Antioxidant activity of extracts from Alchemilla xanthochlora prepared with various extraction solvents over 1 hour at $50^{\circ} \mathrm{C}$. A - antioxidant activity measured by photometric method expressed in $\mathrm{g}$ of DPPH scavening with one $\mathrm{g}$ of crude extract residues; B - qualitative composition of antioxidants measured by TLC-DPPH method ( $\mathrm{H}$ - n-hexane, $\mathrm{CH}$ - chloroform, $\mathrm{E}$ - ethylacetate, $\mathrm{M}$ - methanol, V distilled water).

The TLC-DPPH screening method (Fig. 1) indicated the presence of antioxidant compounds in all tested extracts. The most prominent antioxidant activity was observed particularly in methanolic extract (Fig. 1). The presence of two various groups of antioxidants from Alchemilla xanthochlora were confirmed. The first group of antioxidants represents compounds with lipofilic character such as $\beta$-carotene or lycopene. Compounds from this group are extracted in extraction solvents such as hexane, chloroform, ethylacetate and methanol. The second group of antioxidants comprises compounds with properties like flavonoid or coumarin glycoside. Compounds from this group are extracted in methanol and water. In the literature, 
phytochemical screening on the genus Alchemilla revealed that there are flavonoids (e.g. quercetin-3-arabinopyranoside and quercetin-3-glucuronide) (LAMAISON et al., 1991; FRAISSE et al., 2000), tannins, polyphenols and coumarins (esculetin) (SCHIMMER and ESCHELBACH, 1997). These compounds may be founded in the second antioxidant active group. For the separation of these groups of natural antioxidants, the plant material can be extracted with chloroform and water. The crude extract for another analysis was prepared with methanol to obtain present antioxidants in Alchemilla xanthochlora.

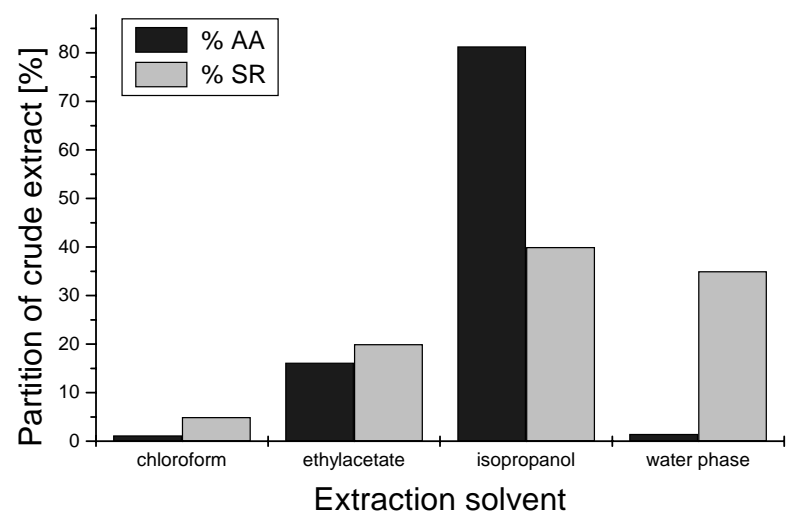

Fig. 2. Effect of the extraction solvent by extraction liquid-liquid on the extraction of antioxidants from crude extract of Alchemilla xanthochlora (\%AA - part of crude extract antioxidant activity in the fractions; $\% \mathrm{SR}$ - part of crude extract residue in the fractions).

At first, the crude methanolic extract was purified to eliminate ballast compounds by liquid-liquid extraction. Three various solvents (chloroform, ethylacetate, isopropanol) and water were used. The suitability of extraction solvent in the extraction liquid-liquid was studied by the percent evaluation of antioxidant activity and solid residue from crude extracts. These parameters were used to describe the purity and efficiency of separation step - extraction liquid-liquid. The results of these experiments are presented in the Fig. 2.

Successive extraction was shown that more than $80 \%$ of antioxidant activity of crude methanolic extract from Alchemilla xanthochlora was cumulated in isopropanol fraction and more than $60 \%$ of crude extract residue was eliminated from isopropanol fraction by these methods. Therefore, the necessity of liquid-liquid extraction of crude extract with isopropanol and water before separation by column chromatography is evident.

Purification of antioxidants from extracts of Alchemilla xanthochlora was executed by column chromatography on the silica gel with gradient elution of chloroform : methanol mixtures. The separation of antioxidants on the column was studied by measuring of radical-scavening activity in obtained fractions (Fig. 3).

Used separation system is suitable for isolation of antioxidants from Alchemilla xanthochlora as for active compounds from first lipofilic group as for active compounds from second hydrophilic group. Antioxidative active compounds were 
cumulated in 5 fractions $(4-5 ; 17-19)$ with high content of antioxidant active compounds.

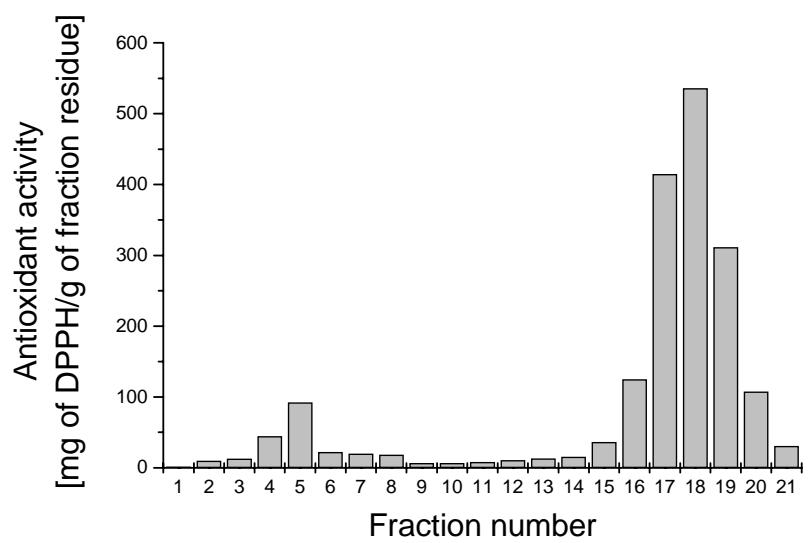

Fig. 3. Antioxidant activity of fractions of isopropanol fraction of crude methanolic extract from Alchemilla xanthochlora. (1-3 - chloroform; 4-6 - chloroform : methanol (9:1)(v/v); 7-9 - chloroform : methanol $(7: 1)(\mathrm{v} / \mathrm{v}) ; 10-12-$ chloroform : methanol $(5: 1)(\mathrm{v} / \mathrm{v}) ; 13-15 \quad-$ chloroform : methanol $(3: 1)(\mathrm{v} / \mathrm{v})$; 16-18 - chloroform : methanol (1:1)(v/v); 19-21 - methanol).

\section{Conclusions}

For the isolation of antioxidants from Alchemilla xanthochlora, extraction of the dried grounded plant material with methanol at $50^{\circ} \mathrm{C}$ during 1 hour with subsequent extraction liquid-liquid of crude extract residue between phases of water and isopropanol and column chromatography on silica gel with gradient elution of chloroform : methanol mixtures were successfully used. Isolated fraction showed specific antioxidant activity $535.2 \mathrm{mg} \mathrm{DPPH}$ to $\mathrm{g}$ of fraction residue. The results of this work may be used for determination of antioxidant active compounds from Alchemilla xanthochlora.

\section{References}

ARNAO, M.B., CANO, A., ACOSTA, M.: The hydrophilic and lipophilic contribution to total antioxidant activity. Food Chem., 73, 2001, 239-244.

DJIPA, C.D., DELMEE, M., QUETIN-LECLERCQ, J.: Antimicrobial activity of bark extracts of Syzygium jambos (L.) Alston (Myrtaceae). J. Ethnopharmacol., 71, 2000, 307-313.

FIKSELOVÁ, M., IVANIŠOVÁ, E.: Byliny a čaje ako potenciálne zdroje prírodných antioxidačných látok. In: Aktuálne problémy riešené v agrokomplexe. SPU, Nitra, 2008, 334-338.

FRAISSE, D., HEITZ, A., CARNAT, A., CARNAT, A.P., LAMAISON, J.L.: Quercetin 3-arabinopyranoside, a major flavonoid compound form Alchemilla xanthochlora. Fitoterapia, 71, 2000, 463-464. 
HAMAD, I., EROL-DAYI, O., PEKMEZ, M., ONAY-UCAR, E., ARDA, A.: Free radical scavenging activity and protective effects of Alchemilla vulgaris (L.). J. Biotechnol., 131, 2007, S40-S41.

LAMAISON, J.L., CARNAT, A., PETITJEAN-FREYTET, C., CARNAT, A.P.: Quercetin-3-glucuronide, main flavonoid of Alchemilla, Alchemilla xanthochlora Rothm. (Rosaceae). Ann. Pharm. Fr., 49, 1991, 186-189.

NAIK, G.H., PRIYADARSINI, K. I., SATAV, J.G., BANAVALIKAR, M.M., SOHONI, D.P., BIYANI, M.K., MOHAN, H.: Comparative antioxidant activity of individual herbal components used in Ayurvedic medicine. Phytochemistry, 63, 2003, 97-104.

PAULOVÁ H., BOCHOŘÁKOVÁ H., TÁBORSKÁ E.: Metody stanovení antioxidační aktivity př́rodních látek in vitro. Chem. Listy, 98, 2004, 174-179

SCHIMMER, O., ESCHELBACH, H.: Esculetin in Alchemilla speciosa: identification and antimutagenic properties. Pharmazie, 52, 1997, 476-478.

TrOUIllas, P., CAlliste, C.A., AllAis, D.P., SIMON, A., MARFAK, A., DELAGE, C., DUROUX, J.L.: Antioxidant, anti-inflammatory and antiproliferative properties of sixteen water plant extracts used in the Limousin countryside as herbal teas. Food Chem., 80, 2003, 399-407. 